\title{
Exploring Trends in Teaching Stylistic Analysis: Syntactical features in Selected British Fashion Magazine "Harper's Bazaar"
}

\author{
Natassa Putri \& Rugaiyah Rugaiyah \\ Universitas Islam Riau, Pekanbaru, Indonesia \\ ruqaiyah@edu.uir.ac.id
}

\begin{abstract}
ARTICLE HISTORY
Received : 2021-02-05

Revised : 2021-03-25

Accepted : 2021-03-30
\end{abstract}

\section{KEYWORDS}

Stylistic

Stylistical Feature

Advertisement

Universitas Islam Riau

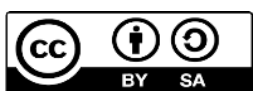

\begin{abstract}
Teaching English Stylistic to language students in Universitas Islam Riau has always been part of language or foreign language education. It is a study of linguistic which studies about how someone expresses his or her ideas depend on the purpose of it. An advertisement is good example to study to see the advertisers use a language to persuade the readers to buy their product or use their service. This research attempted to know the style of language on advertisement, namely syntactical feature in stylistic teaching-learning frameworks. This research used descriptive qualitative as the research design and textual analysis was used to analyze the data. There were 28 data from two editions of Harper's Bazaar UK magazine. Based on the data obtained, it is found that there were 46 long-noun phrases, 16 short sentences in the form of present tense, 13 imperative and ellipsis, 3 incomplete sentences and association, 1 for simple and colloquial, ambiguity, syntactic parallelism. Students are required to have literary competence as they are exposed to extracts from literary works while studying English.
\end{abstract}

\section{Introduction}

In everyday life, people exchange information through the use of a language. The role of language in our lives is therefore important as a means of communication. (Bloomfield, 1962, p. 3). As time passes, the use of language has been increasingly developed through the presence of social media. Social networking has become an essential communication tool for linking individuals and organizations effectively. However, The function of social media in language depends on its value for transmitting a specific message. Language has several purposes, one of which is to convince the addressee to do something that the speaker needs. People are persuading others through the words. As Trimmer and Nancy (1984) have pointed out, persuasion is a verbal contact that makes it possible for people to have a certain judgment or to alter their previous judgment to support a new one that they have not previously believed. People persuade others to change their points of view.

Therefore they're going to believe what people say. Besides language is also flexible because it allows human to work and interact by expressing their ideas based on their purpose. Language and media spread widely nowadays and linguistics' elements still can't be separated from it. It is because there is a language in there. Language which is written in media such as books, magazines, and newspapers have some characteristics and they are different from each other's. Just taking a look at the writing from each of it. One example, there is a book called A and another one is called B. The style of book A is written is different from book B. Maybe it because of the author, the theme, or even the genre is different. Even the author or the writer is the same person, the style of both of the books is still different; there is something that differs both of the book. In linguistics, there is also a branch of it that discusses about the way or the style something is written or spoken. It actually often relates more to the literature and it is called stylistics. Stylistics, as defined by Evangeline and Fomukong (2016), is a study about language that focuses on style in a language. Stylistics is a critical approach, not limited to the study of literature (Barry 2002, p. 203). This study used of non-literary work as results. The approach and the caption are connected because the caption is diverse and each company has its own style of writing the caption. For this purpose, a stylistic approach is necessary in order to find the style and the inspiration of the caption.

This study focuses only on syntactic features of publications by analyzing the stylistics on advertisement in a women fashion magazine in "Harper's Bazaar". This is due to it is the first American fashion publication, Harper's Bazaar, has 
been presenting the visions of renowned editors, photographers and stylists since 1867. In November 1970, Harper's Bazaar UK (founded in 1929) and Queen's Magazine (dated in 1862) amalgamated to form Harpers \& Queen. The magazine concentrated on the British "high society" and the life of the socialites and the British aristocracy. Over the last five years, it has repositioned itself as Harper's Bazaar, taking it into line with its foreign sister names

Grey (2008) divides the linguistic features of advertisement into two parts: the lexical and the syntactic. However, in the traditional college English lesson teachers spent most of the time on language points and grammar. The teacher discusses primarily the language and grammar of the article in class; the whole class is grammar and translation practice. Therefore, the teacher could not guide the student to a profound understanding of the written style and feature of the article and thus failed to comprehend and appreciate the whole article. The final outcome of traditional training is that students only have certain basic vocabulary and grammar skills. For example, students do not have a concept of a register during the reading process, let alone the writer's writing and thought mode. Eventually, The English skill of the students is limited to the mastery of language analysis and sentence analysis. This form of spoon feeding does not completely mobilize the participatory feeling of students, which does not help to boost the independent capacity of students to learn and hampers the growth of student reading understanding.

Therefore, innovative education allows English college teachers to continually refresh their teaching concepts. Stimulating open-mindedness in one's own mind and allowing people to see different ways of approaching a problem or learning allows college English teachers to be actively learning and rephrasing their approach to problem solving. There are two important reasons to taking college English classes: to learn a foreign language and to expand one's skills. In order to improve the capacity of college students to learn English in an all-encompassing way, teaching English in universities should represent the spirit of general education.

Treating the educator as an individual who possesses an in-depth set of values as well as a full values is a key tenet of good education. an education which focuses on the harmonious development of the lives, morality, feelings, and purpose of the teachers General education stresses the incorporation and synthesis of knowledge and enhances students' ability to express themselves, consider, criticize and innovate. Consequently, the teaching mode dependent on language skills must be rebuilt.

Teaching is not teaching, teachers should offer education to students, encourage them to learn to think, and then use their own innovative thinking to learn, to learn. The educational concept of people-oriented in general education must be established by college English teacher, who train students to be personal, analytical, independent thinkers and innovative so as to enable them to learn the English language in a lasting manner.

Morever, Bekkar, M., \& Ouerrad, B. (2021) applied some of the approaches to teaching literature and provides a rationale for integrating the teaching of literature as an approach to language classroom. For university teachers, the study of literature is indispensable because it exposes students to meaningful contexts. Further, they .Integrating reading comprehension and written expression at university involves the effectiveness of literature type and the objectives planned. Healey, B., \& Gardner, P. (2021) claim that development of the metalinguistic understanding of students is essential to make informed language choices when writing, While, Rugaiyah (2018), Dj, M. Z., Telaumbanua, S., Rugaiyah, S. S. G., Husna, F., \& Pramesworo, I. S. (2020) Learning must be contextual so that learners find meaning in their learning by connecting academic material based on content in their daily life

\section{Literature Review}

There are many uses of language that decide how a writer or speaker selects phrases, syntactic expressions and figurative language. This is the product of the fact that language has a very strong influence on people, their actions and their emotions. This is seen in the use of language in different forms of discourse, including ads. As a result, the powerful effect of language on people makes encoders chosen in the use of language particularly in advertising, And the readers have to be convinced. They thus make the vocabulary of the advertising optimistic and stress the superiority of their goods.

Thangamarimuthu, M. B., Sindhu, M. S., \& Pandiyaraja, M. M (2021) had analyzed Tennyson's poem "Break, Break, Break" from a stylistic point of view. The analysis is made under the aspects of graphological, phonological and semantic point of view. They found that it helps readers in understanding the basic linguistic concepts and literary ideas of the poem with the ability to reasoning. Furthermore, it highlights the difference between ordinary languages used in daily life compared to the literary language that is used in the poetic text. Besides, Memon, M. I., \& Farhat-un-Nisa Tunio, M. A Have done their research about A stylistic analysis of the poem 'If' by Rudyard Kipling on three fundamental levels: phonological, morphological, and pragmatical. The poem has been a source of inspiration for disheartened youth, and is a linguistic marvel because of its unique structure and style. It Helps the readers to understand the core Stylistic principles and concepts which the poet aesthetically uses in his poem 'If.". 
Furthermore, Rashid, M. N., \& Abdulla, S. A. F (2018) show that Allan uses certain linguistic deviation in the selection of some of the lexical categories that expresses the narrator's deep feeling through the uses of lexical deviation to create a sense of ambiguity that brings an aesthetic value of the text.

\subsection{Advertisement}

Advertisement is a form of communication that is used to increase a company's profit by persuading the readers to buy their product (Baba, 2012). Advertisements, or often shortened as ads, contain pictures and sentences because the purpose of it is to attract the readers' attention to buy the product or to use the service. The pictures or several things that similar to them like icons and doodles are made as attractive as they could to captures someone's attention easily. Moreover, the reason of using pictures is because humans' brains are attracted to things that have colours easily. Another feature in advertisement is text; it is usually in a form of phrases only, or short sentence.

Today, with globalization and industrialisation spreading widely, many goods are sold on the market. This means that a product must compete on the market with another product. Marketing has a big role to play because of this. Therefore, advertisers must be more intellectual in order to persuade people to buy or use their product. Media advertisement has established a specific form of language that differs from a book or journal's language ( $\mathrm{Li}, 2009)$.

Furthermore, there is a reason why advertisements contain texts on it. As stated by (Evangeline \& Fomukong, 2016), language, whether it is in a written form or non-written form has a power to affect people's thoughts and actions. Because language itself is not rigid and can develop from time to time to suit human's life and can be used in different situations. However, the texts that are shown in advertisements must have the answer of these three things: 1) What is being advertised? This question leads to the product or the idea that are being advertised; 2) Who is being addressed? The second question discusses about the people that are targetted for the advertisement. Is this advertisement addressed for children, or for adults? For women or for men?; (Goddard, 2001) and the last is 3) The message, so that the purpose of the advertisement can be achieved by people buy the products or use the service.

The most important thing in advertisement is the use of a language. It is because language has the powerful impact towards someone's mind and action (Evangeline and Fomukong, 2016). That's why the usage of a language in the description of the advertisement, starting from the choice of words, the syntactical feature, and others must be selected carefully. An advertisement with a simple picture and a sentence can be very powerful if the sentence uses a right language. Only with one sentence, the readers can pay their attention and want to buy a product or use the service. Because of that, many advertisements use language features to attract the readers. One of the language features is syntactical feature such as the use of imperative, incomplete sentence, etc.

Njemanze et al., (2015) stated that advertisements contain information; it gives the reader some important information about a product and persuades them to buy the product too. In gathering information, advertisement in magazine or any other printed media should have a concise yet informative and attractive description about the things that are being advertised. Advertisement in printed media usually only has one or two pages per product because the pages in the magazine are also limited. In order to maximize the usage of the pages, the description of the product or a service must be concise and can attract readers' attention easily. The elements in advertisement are also needed to be arranged. The combination of colours, fonts, styles of the text are also important. To conclude, the description of an advertisement in a magazine should be unique to attract and persuade the readers.

In addition, an advertisement has its own unique language type. The style of the advertisement is about stylistics, in particular language characteristics. Four types of printed advertising are described in Vaicenoienè, (2006), which are lexicographical devices, rhetorical devices, syntactic features and publicity registers.

\subsection{Stylistics}

Stylistic approach is "a critical approach using linguistic approaches and studies of literary text review". This method means that the data from a literary text are classified into smaller sections like phrases, sentences or sentences and then identified to find those characteristics. However the entire text is not a stylistic solution. It only selects the segment that the readers want to hear. "We do not concentrate so much on every shape and structures in a text in our stylistic review as on those that stand out there (Verdonk, 2002, p. 6). Burke (2014) stated that stylistic is a study and analysis that is done by analyzing texts, in particular and the origins of stylistic was analyzing literary texts. These days, stylistic doesn't only analyze literary texts; it develops into texts in advertisements, slogans, and others. That is why the researcher is interested to analyze the advertisements to discover about how the advertisers express their ideas into a form of writing text to persuade the readers to buy the product or use their service.

Moreover, Nurgiyantoro (2014) added that stylistic is a study about style which is how someone expresses his or her ideas and can achieve the aesthetic. Another definition about stylistic which also contains more depth about stylistic is by Jeffries and McIntyre (2010) 
who said that stylistic discusses a language use in any range. It means that stylistic doesn't only discuss about written language like in the past, but also spoken language which makes the field that can be analyzed also broader. Style in any media such as newspaper, books, poster, and others can be analyzed. This includes advertisements.

\subsection{Syntactical Features}

Linguistic features is an extremely broad phrase. In context of translating, a variety of a language used for a particular purpose or in a particular social setting, a sociolect, ethnolect, etc. dialect, slang, idiomatic expressions. In linguistics, a feature isany characteristic used to classify a phoneme or word. These are often binary or unary conditions which act as constraints in various forms of the linguistic analysis. According to Permatasari and Yulia (2016), syntactical features on the advertisement has a function to attract the readers' attention easily because how simple the language is. Syntactical features on advertisement also deals with grammatical aspect in a language because the features relate to the arrangement of words and phrases.

\begin{tabular}{|c|c|c|c|}
\hline NO & $\begin{array}{c}\text { Syntactical } \\
\text { Features }\end{array}$ & Description & Example \\
\hline 1 & $\begin{array}{l}\text { Short } \\
\text { Sentence }\end{array}$ & $\begin{array}{l}\text { Subject + } \\
\text { Predicate }\end{array}$ & $\begin{array}{l}\text { Nothing } \\
\text { compares to } \\
\text { a Magnum }\end{array}$ \\
\hline 2. & $\begin{array}{l}\text { Long-Noun } \\
\text { Phrase }\end{array}$ & $\begin{array}{l}\text { Consists more } \\
\text { than one noun }\end{array}$ & $\begin{array}{l}\text { Parking } \\
\text { meters credit } \\
\text { card }\end{array}$ \\
\hline 3. & Ambiguity & $\begin{array}{l}\text { The meaning } \\
\text { has more than } \\
\text { one } \\
\text { interpretation }\end{array}$ & $\begin{array}{l}\text { I need new } \\
\text { glasses }\end{array}$ \\
\hline 4. & $\begin{array}{l}\text { Use of } \\
\text { Imperative }\end{array}$ & $\begin{array}{l}\text { Begins with } \\
\text { verb }\end{array}$ & $\begin{array}{l}\text { Go Away! } \\
\text { Do it } \\
\text { yourself. }\end{array}$ \\
\hline 5. & $\begin{array}{l}\text { Simple and } \\
\text { Colloquial } \\
\text { Language }\end{array}$ & $\begin{array}{l}\text { Informal } \\
\text { language used } \\
\text { by people in } \\
\text { daily speech }\end{array}$ & $\begin{array}{l}\text { Bentley (it's } \\
\text { not a name } \\
\text { of a place. } \\
\text { It's a name } \\
\text { of car brand) }\end{array}$ \\
\hline 6. & $\begin{array}{ll}\text { Use } & \text { of } \\
\text { Present } & \\
\text { Tense } & \end{array}$ & $\begin{array}{l}\text { Subject + } \\
\text { V1(s/es) }+ \\
\text { Object or } \\
\text { complement }\end{array}$ & $\begin{array}{l}\text { The plane } \\
\text { leaves for St. } \\
\text { Lucia } \\
\text { tomorrow. }\end{array}$ \\
\hline 7. & $\begin{array}{l}\text { Syntactic } \\
\text { Parallelism }\end{array}$ & $\begin{array}{l}\text { It's a } \\
\text { repetition of } \\
\text { the same } \\
\text { structural } \\
\text { pattern. }\end{array}$ & $\begin{array}{l}\text { Out of sight, } \\
\text { out of mind }\end{array}$ \\
\hline 8. & Association & $\begin{array}{l}\text { Showing } \\
\text { positive side } \\
\text { of the product } \\
\text { and relates it } \\
\text { to something } \\
\text { that is not }\end{array}$ & $\begin{array}{l}\text { All gold } \\
\text { chocolate }\end{array}$ \\
\hline
\end{tabular}

\begin{tabular}{|c|c|c|c|}
\hline & & $\begin{array}{l}\text { relevant (can } \\
\text { be a picture) }\end{array}$ & \\
\hline 9. & Ellipsis & $\begin{array}{l}\text { Subject, verb } \\
\text { or object is } \\
\text { omitted } \\
\text { because the } \\
\text { hearer or } \\
\text { reader will } \\
\text { still } \\
\text { understand } \\
\text { the meaning. }\end{array}$ & $\begin{array}{l}\text { Jack fell } \\
\text { down and } \\
\text { (he) broke } \\
\text { his } \\
\text { homecoming } \\
\text { crown }\end{array}$ \\
\hline 10. & $\begin{array}{l}\text { Incomplete } \\
\text { Sentence }\end{array}$ & $\begin{array}{l}\text { Subject or } \\
\text { verb is } \\
\text { missing to } \\
\text { emphasize the } \\
\text { point. They } \\
\text { aren't } \\
\text { grammatically } \\
\text { full sentence. }\end{array}$ & $\begin{array}{l}\text { L'Oreal. } \\
\text { Because you } \\
\text { are worth it! }\end{array}$ \\
\hline
\end{tabular}

\section{Method}

This research used descriptive qualitative as research design. Descriptive, as described by Zuriah (2006) is a research that has an aim to present facts, events, and phenomena and the research is presented systematically and accurately. For the analysis, textual analysis was used (Wales 2014). Textual analysis is a method of data analysis which analyzes the content or the structure of the text. The data were obtained from Harper's Bazaar magazinepublished in September 2019 and in April 2020 editions. Total of the data was 28 advertisements which contain written texts on those. For the instrument, documentation was used. Rugaiyah (2016) stated that documentation is a tool which is used by the researchers to help them to collect data from written text such as publication, letters, and others.

\section{Results and Discussion}

Table 1. Stylistic found in Harper's Bazaar

\begin{tabular}{|c|c|c|}
\hline No & $\begin{array}{l}\text { Type } \\
\text { Stylistic }\end{array}$ & Phrases/ sentences \\
\hline 1 & Ambigiuty & Genius is born crazy \\
\hline \multirow[t]{2}{*}{2} & Association & She's a fun \\
\hline & & Sparkling soiree \\
\hline \multirow[t]{2}{*}{3} & Ellipsis & $\begin{array}{l}\text { Masters in luxury travel since } \\
1988\end{array}$ \\
\hline & & $\begin{array}{l}\text { (Dr. Pawpaw is) made with } \\
\text { natural pawpaw fruit }\end{array}$ \\
\hline \multirow[t]{2}{*}{4} & $\begin{array}{l}\text { Incomplete } \\
\text { Sentences }\end{array}$ & $\begin{array}{l}\text { Introducing the twenty-4 } \\
\text { automatic }\end{array}$ \\
\hline & & $\begin{array}{l}\text { The signature serpent kaftan } \\
\text { available exclusively at Zaeem } \\
\text { Jamal }\end{array}$ \\
\hline 5 & $\begin{array}{l}\text { Long-Noun } \\
\text { Phrase }\end{array}$ & $\begin{array}{l}\text { Double Wear Makeup, 24-hour } \\
\text { staying power, Flawless }\end{array}$ \\
\hline
\end{tabular}




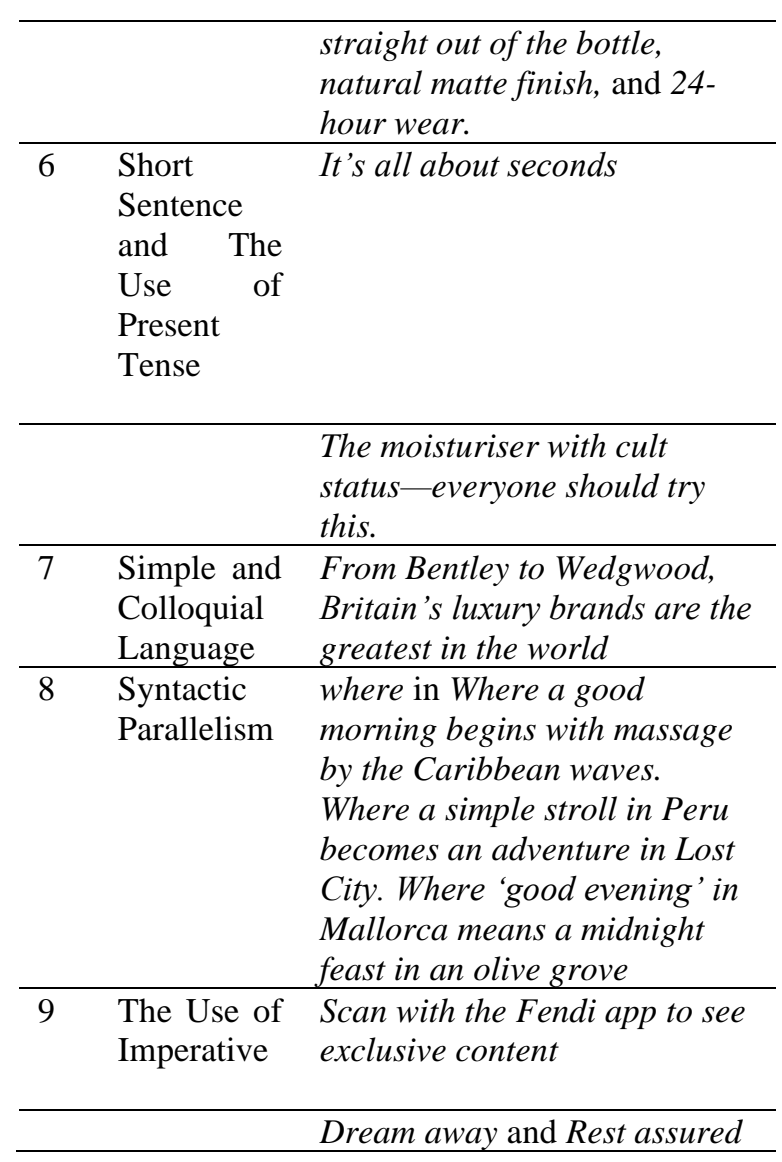

Based on the Table 1 above it shows that there are 6 types of Stylistic found on Advertisements in British Fashion Magazine Found in Harper's Bazaar,

\section{Ambiguity}

Ambiguity is usually defined as something that has more than one meaning. Sentences or utterances that have ambiguity in it usually mean that those sentences or utterances have more than one meaning that can be interpreted by the readers or the listeners. Ambiguity is also different depends on its principal. In linguistics, ambiguity can be in a form of a grammatical ambiguity (in phrases or sentences) and lexical ambiguity (in words). However, in certain registers, ambiguity also relates to humorous things such as jokes, puzzles, and riddles (Wales, 2014). From the analysis of all of the data, one ambiguity is found. It is an advertisement of clothing brand. The text is in a form of short sentence and it says Genius is born crazy. Further, the short sentence Genius is born crazy can be ambiguous too. Is the meaning people who are genius are born as a crazy (people with mental illness) people? Or does it imply any other meaning? If the readers did a research about the meaning, this advertisement which is a clothing brand, explores people with highly genius mind whose creativity has inspired the world. The people are also a little bit different but in a good and creative way so that's why they can inspire the world by their creativity.
Association in here means that sometimes advertisement uses the positive side of the product that is being advertised with something else that somehow is not related to (Purba, 2013). In other cases, association can also happen when the advertiser relates the sentence or the description of the product with a picture of it. The purpose is to attract the readers' attention.

Association in advertisement can also occur when the advertiser associates the product or the service with the image or cultural value. The mascot of the Mandarin Oriental hotel in data 8 is a fan, and the advertiser associates the fan and the brand ambassador, Helen Mirren, that she is a fan (meaning that she admires) of the hotel.

The word sparkling in data 9 is associated with the picture of the bag that is designed with crystals and metallic colours. Crystals and metallic colour will sparkle when exposed to light. This is associated with soiree which is a private, luxurious gathering party.

\section{Ellipsis}

Ellipsis relates to the grammar which means something is removed with the aim of the listener or the reader has understood the meaning of the sentence even though there are parts that are omitted (McCarthy, 1991). Ellipsis usually focuses on important information and even some parts (namely words) are omitted, the meaning of the sentences doesn't change and can still be understood. Ellipsis is common especially in speech, but it should be avoided if the meaning changes into ambiguity meaning.

It is Masters in luxury travel since 1988. It is actually (Elegant Resorts) masters in luxury travel since 1988. The subject, which is the name of the resort, is deleted because it is assumed that the readers already understand the meaning. Moreover, the concise explanation can attract readers' attention to have a holiday in their resorts.

Then, Made with natural pawpaw fruit is the ellipsis. There is a part of the sentence is deleted because the speaker or the advertiser here assumes that the hearer (or the readers) will understand the meaning even there is a part that is deleted. On the other, it is actually (Dr. Pawpaw is) made with natural pawpaw fruit. The subject and the verb is is deleted because the subject, Dr. Pawpaw, which is also a name of the brand and written above the ellipsis, and the purpose is to attract the readers' attention. Another purpose is to make the explanation of the product concise and the readers still understand the meaning.

\section{Incomplete Sentences}

Incomplete sentences are also often found in many advertisements. A simple complete sentence consists of subject and a verb. However, in advertisements, sometimes a subject (a noun) is 
missing or a verb is missing in order to emphasize the point and to save some spaces (Purba, 2013).

Introducing the twenty-4 automatic is an incomplete sentence in the advertisement 3. It begins with the word Introducing, a continuous form of introduce. If the sentence is complete, then it must be (Patek Phillipe is) introducing the twenty-4 automatic. The purpose of incomplete sentence on advertisement is to cut the information that is not necessary so that the readers will focus on the main point of the advertisement. In term of meaning, the twenty-4 automatic actually has implied meaning. It is also stylised as twenty-4 instead of twenty four or 24. It's because the watch itself is a brand new model watch and new series of self-winding mechanical ladies watch. This is a pragmatic meaning. Then, the verb is in The signature serpent kaftan available exclusively at Zaeem Jamal. The verb is is actually put between kaftan and available. So it is The signature serpent kaftan (is) available exclusively at Zaeem Jamal.

\section{Long-Noun Phrase}

Noun phrase is a term that can be found in grammar because it refers a structure which has head that consists of noun or pronoun, with or without a modifier. There are also noun phrases that consist of more than one noun rather than adjective; this type of noun phrases can be called as heavy nominal group or it can be simply called as long-noun phrase. This heavy nominal group can be found usually in newspaper headline. From analysis that has been done, long-noun phrase is the syntactical feature that is most commonly found among the advertisements.

Sometimes a noun can be followed not only by adjective, but also by a noun or more than one noun. It is called as long-noun phrase. In data 1, long-noun phrases that can be found are Double Wear Makeup, 24-hour staying power, Flawless straight out of the bottle, natural matte finish, and 24-hour wear.

Double is adjective, wear is a noun, and makeup is a noun. The second one, 24-hour is a noun, staying is also a noun, and power is a noun. The third one, flawless is adjective, straight in there is adverb, out is also adverb, of is a preposition, the is a particle, and bottle is a noun. The fourth one, natural is adjective, matte is adjective, and finish is noun. The last but not least, 24-hour wear and they are nouns. Long noun phrases are added to the advertisement to make the product stands out even more.

\section{Short Sentence and the Use of Present Tense}

Advertisements usually don't last for a long time and that's why the language in the advertisements should make a longstanding effect to the readers. In magazine, the readers usually just glance once on an advertisements and a short sentence that makes an impact to the readers is needed. The function of the short sentence in here is to attract the readers' attention (Purba, 2013).

As has been already known, present tense is a tense that is commonly used. In advertisement, the use of present tense leaves a good impact because it gives such a real sense to the readers or the consumers. When using present tense, the products and information that are being advertised can create the effect that the advertisement is true and attract the readers to buy the product or use the service (Purba, 2013). In this part, the explanation of short sentence and the use of present tense are combined because based on the result of data analysis, all of the short sentences use simple present tense. Sixteen short sentences that use present tense are found. Further, Short sentence that can be found in data 6 is It's all about seconds. As has been elaborated above, short sentence consists of subject and predicate. The subject in the sentence is it and the verb is is. All about seconds acts as object.

In term of meaning, semantically, seconds in there refers to every single second (time) that is spent by women (because this watch is for women) is important. There is a website in the advertisement so that the readers can read more about Chanel The New J12 watch. The meaning of seconds, if the readers know the background of the watch is when women cross the street, meet someone new or change the course of their destiny, each of it is a story of decisive seconds for women's life. The ads implies that it's important for the women to buy the right watch (Chanel's watch) for every second of their life.

It is The moisturiser with cult status-everyone should try this. This sentence consists of long-noun phrase The moisturiser with cult status-everyone, followed by auxiliary should and verb try, then an object this. This short sentence, which is a review by beauty director, really suggests the reader to try the moisturiser beause it has cult status, means that the moisturiser is loved by many people. This in there refers to the Lixirskin Universal Emulsion.

\section{Simple and Colloquial Language}

Colloquial language is a language that is used in human's daily life and it is usually used in informal language. Colloquial language and vocabularies used by the speakers may last longer than vocabularies in slang because colloquial language usually is not for a specific group. Colloquial language can be found in advertisements too because it is simple and the language is easy to understand. Moreover, a simple language can attract the readers easily.

Even colloquial language is a language that is used by human in the daily life, colloquial language can not be equated with slang. Slang is usually used in human's daily life too but there is something that differentiates colloquial and slang. Slang is usually used by teenagers or other specific groups in a specific places or area 
while colloquial language is used by people in their daily speech and the words that are used are known by a larger people, not only in a specific group.

From Bentley to Wedgwood, Britain's luxury brands are the greatest in the world. To be exact, it is Bentley and Wedgewood. Colloquial language is a language used by ordinary people in their daily speech and it is usually not related into specific groups or specific ages of the speakers. For those who are not the native speaker of English might be confused because Bentley is actually a name of place in England too. But for the English speakers, especially in Britain, must be know that Bentley in there means a luxury cars name, Bentley Motors Limited. That is how they usually say the brand in their daily speech. So is Wedgwood. People who aren't native speakers might wonder about Wedgwood. Is it a place? Or what kind of the brand is that? But English speakers, especially in Britain will know that it's a luxury porcelain brand that is very famous in there.

\section{Syntactic Parallelism}

Parallelism is common in phrases or clauses. It is a repetition of the same structural pattern and there is a connection between the units in term of meaning. (Wales, 2014) stated that alliteration and the pattern of the sounds make parallelism more prominent such as the pattern of the sounds in a poem and others. Parallelism can attract the readers' attention too and it can be found in some advertisements. Same as simple and colloquial language, there is only one syntactic parallelism that can be found from all of the data.

Syntactic parallelism is a repetition of the same structural pattern in a sentence or phrase. It can be seen that the word where in Where a good morning begins with massage by the Caribbean waves. Where a simple stroll in Peru becomes an adventure in Lost City. Where 'good evening' in Mallorca means a midnight feast in an olive grove repeats and it is a syntactic parallelism.

\section{The Use of Imperative}

Imperative is a kind of sentence that has commands and directives which have more broader scopes such as orders (e.g: Stop!), requests (e.g: Kindly refrain from smokin), and instructions (e.g: Check that the wiring is correct) (Wales, 2014). This type of sentence usually begins with verb, like Go away!. The subject of this sentence is assumed as second person pronound, you. In the magazine's advertisements, imperative is used to make the readers buy the products that are being advertised. There are thirteen imperative form are found from the advertisement. Imperative sentence is a sentence that contains commands or directives in it. In this advertisement, it can be seen that the sentence Scan with the Fendi app to see exclusive content is an imperative sentence omit the subject you. It gives the readers an order or direction to scan the application of Fendi brand to see more products and exclusive content in there. The brand also will get benefit too if the readers download the application on their phones.

Dream away and Rest assured. Those two imperatives are verb phrases. They consist of two words, but it only has one meaning. The advertisers mean that they told the readers to go to a vacation without a doubt with their travel agency because their travel agency is trusted. As the name suggests, The Thinking Traveller has a comfort that is offered to think, relax, and found ideas or just to clear the consumer's mind.

\section{Conclusion}

There are some syntactic features are found in the British fashion magazine, Harper's Bazaar. They are long-term phrases, short sentences, the use of imperatives, ambiguity, the use of present tense, association, ellipsis, incomplete sentences and simple and colloquial language. The stylistic style used in "bazaar" appears to emphasize the unity of the structural and pragmatic scope of the studies. So, the interrelations of various language levels and the power of analysis to clarify messages, the meanings and consequences of the authors.

Moreover, the occurrence of the linguistic elements means to make the sentence more imaginative and simple for target audiences, such as networkers, to be recognized, which becomes the principal goal of ads for goods that function as the role of advertising. Thus 28 data from two editions of Harper's Bazaar UK magazine will achieve their goal of persuading and attracting customers to the branded product.Further, Stylistics is the most significant study of all linguistic courses offered. It is twice as long, is based on prerequisite grammar and lexicological skills and combines English knowledge and comprehensive reading experience. Besides,

\section{References}

Barry, Peter. (2002). Beginning Theory. Manchester: Manchester University Press.

Bekkar, M., \& Ouerrad, B. (2021). Building Literacies at Tertiary Level: Integrated Tests for Reading Comprehension and Written Expression to Algerian University Learners. English Language Teaching, 14(1), 64-73.

Bloomfield, Leonard. (1962). Language. London: Allen and Unwin

Burke, Michael. (2014). The Routledge Handbook of Stylistics. Oxon: Routledge.

Dj, M. Z., Telaumbanua, S., Rugaiyah, S. S. G., Husna, F., \& Pramesworo, I. S. (2020). Application of Beyond Centers and Circles Time Method to Improve Writing Skills and Scientific Attitude of Prospective English Learners. Universal Journal of Educational Research, 8(10), 4939-4945. 
Fomukong, Seino \& Evangeline, Agwa. (2016). Stylistics Analysis in Advertising Discourse: A Case of Dangote Cement Advertisement in Bamenda- Cameroon. Advances in Language and Literary Studies, 7. 105-112.

Given, Lisa M. (2008). The SAGE Encyclopedia of Qualitative Research Methods. USA: SAGE Publications Inc.

Grey, D. (2008). Language in Use. Cambridge: Cambridge University Press.

Healey, B., \& Gardner, P. (2021). Writing, grammar and the body: a cognitive stylistics framework for teaching upper primary narrative writing. Literacy.

Jeffries, Lesley \& McIntyre, Daniel. (2010). Stylistics. Cambridge: Cambridge University Press.

Li, Min. (2009). The Stylistic Analysis of The Magazine Advertisement---Atkins Chocoloate Chip Granola Bar. Asian Social Science, 5(9). 6369.

Njemanze, et al. (2015). Analyzing the Advertising Language of the Mobile Telephony in Nigerian Newspapers: A Stylistic Approach.International Journal of Hummanities and Social Science, 5, 6(1). 136-144.

Nurgiyantoro, Burhan. (2014). Stilistika. Yogyakarta: Universitas Gadjah Mada.

Permatasari, Sonia Niken \& Yulia, Made Frida. (2016). An Analysis on Language Style of the Utterances in Magnum Advertisements. LLT Journal, 16(1). 31-40.

Purba, Titin Ardilla. (2013). Stylistic Analysis on Magazine Advertisement. Universitas Islam Riau.

Putrayasa, I. B. (2021). Political language variation: stylistic based study. Linguistics and Culture Review, 5(1), 1-9.

Rashid, M. N., \& Abdulla, S. A. F. (2018) A Stylistic Analysis of Selected Representative Samples of Claire Allan's Her Name Was Rose. The Scientific Journal of Cihan University-Sulaimaniya PP, 1 , 14

Rashid, M. N., \& Abdulla, S. A. F. (2018) A Stylistic Analysis of Selected Representative Samples of Claire Allan's Her Name Was Rose. The Scientific Journal of Cihan University-Sulaimaniya PP, 1 , 14

Rugaiyah, R. (2018 ). The Benefits of Filed Trip Strategy at Junior and Senior High Schools: An Overview. In proceedings of the 65th TEFLIN international conference (vol. 65, no. 02).

Rugaiyah. (2016). Pengantar Penelitian Kualitatif dan Analisa Bahasa. Pekanbaru: Forum Kerakyatan.
Thangamarimuthu, M. B., Sindhu, M. S., \& Pandiyaraja, M. M.(2021) A Stylistic Analysis of Alfred Lord Tennyson's Poem "Break, Break, Break”. LITERARY DRUID.

Trimmer, J.F \& Nancy, L.S. (1984). Writing with a purpose. Boston: Houghton Mifflin Company.

Vaičenoienè, J. (2006). The language of advertising: Analysis of English and Lithuanian advertising texts. Studies about Language, 4(4), 36-51.

Verdonk, P. (2002). Stylistics. Oxford: Oxford University Press.

Wales, Katie. (2014). A Dictionary of Stylistics: Third Edition. New York: Routledge.

Zuriah, Nurul. (2006). Metodologi Penelitian Sosial dan Pendidikan: Teori-Aplikasi. Jakarta: PT Bumi Aksara. 